\title{
Can miliary tuberculosis be an indicator for tuberculous meningitis? Evaluation of the twenty-five adult cases with meningitis accompanied by miliary tuberculosis
}

\author{
Sevtap Gursoy ${ }^{1}$, H. Ahmed Kehribar², Kadriye Kart Yasar'1, Semsi Nur Karabela', Özlem A. Aydin², M. \\ Emirhan İsik², E. Rahsan İnce², Mehmet Bakar' ${ }^{1}$ Filiz Pehlivanoglu², Gonul Sengoz ${ }^{2}$ \\ ${ }^{1}$ Department of Infectious Diseases and Clinical Microbiology, Bakirkoy Dr. Sadi Konuk Training and Research Hospital, \\ Istanbul, Turkey \\ ${ }^{2}$ Haseki Training and Research Hospital, Bakirkoy Dr. Sadi Konuk Training and Research Hospital, Istanbul, Turkey
}

\begin{abstract}
Objective: This study aimed to compare the characteristics of the tuberculous meningitis (TBM) patients with and without miliary tuberculosis (TB).

Methods: Twenty-five patients with miliary TB of 160 patients with TBM were included in this retrospective study. Diagnosis of TBM was based on anamnesis, clinical and laboratory results, neuroradioogical signs and "Thwaites' Diagnostic Index" while miliary TB was diagnosed by radiological imaging. Statistical analyses were performed using Chi-square test.

Results: Of 25 patients with miliary TB, 14 were female and the median age was 35.3. Ages ranged between 20-35 and 17-78 years in male and female subjects, respectively. Most common symptoms at baseline were headache (84\%), malaise-anorexia (68\%) and nausea-vomiting (64\%) while the most common findings were nuchal stiffness (84\%) and fever (68\%). The patients with miliary TB revealed longer symptom duration and higher rates of malaise-anorexia, night sweats, weight loss and higher protein levels in CSF than the others $(p<0.05)$.

Conclusion: Miliary TB could be an indicator for TBM in countries with high prevalence of TB. Female predominance, longer symptom duration and higher protein levels in CSF were remarkable in the patients with TBM accompanied by miliary TB. J Microbiol Infect Dis 2016;6(2): 74-79
\end{abstract}

Key words: Miliary tuberculosis, Mycobacterium tuberculosis, tuberculosis.

\section{Miliyer tüberküloz menenjit için ipucu olabilir mi? 25 erişkin miliyer tüberkülozlu menenjit olgusunun değerlendirilmesi}

\section{ÖZET}

Amaç: Bu çalışmada, miliyer akciğer tüberkülozu (TB) olan ve olmayan tüberküloz menenjitli (TBM) olguların özelliklerinin karşılaştııılması amaçlanmıştır.

Yöntemler: TBM'li 160 olgudan miliyer akciğer TB'si olan 25 olgu retrospektif bu çalışmaya dahil edilmiştir. TBM tanısl; anamnez, klinik ve laboratuvar özellikleri, BOS ve nöro-radyolojik bulgular ve "Thwaites' Diagnostik İndex" aracılı̆ıyla konmuştur. Miliyer TB tanısı radyolojik olarak konmuştur. İstatistiksel analiz ki kare testiyle yapılmıştır.

Sonuçlar: Yaş ortalaması 35.3 olan 16'sı kadın, dokuzu erkek 25 olgunun yaş aralığı erkeklerde 20-35 iken, kadınlarda 17-78 idi. Başvuru sırasındaki en sık semptom baş ağrısı (\%84), halsizlik-iştahsızlık (\%68) ve bulantı kusma (\%64); en sık bulgu ise ense sertliği (\%84) ve ateşti (\%68). Miliyer TBM'li olgularda miliyer TB'si olmayanlara göre semptom süresi daha uzun ve halsizlik-iştahsızlık, gece terlemesi, kilo kaybı ve BOS'ta protein seviyesi daha yüksek idi $(p<0.05)$.

Tartışma: Miliyer TB, tüberküloz prevalansının yüksek olduğu ülkelerde TBM tanısı için bir ipucu olabilir. Kadın cins hakimiyeti, daha uzun semptom süresi ve BOS'ta protein seviyesinin yüksekliği miliyer TB'si olan TBM'li olgularda dikkat çekici bulunmuşstur.

Anahtar kelimeler: Miliyer tüberküloz, Mycobacterium tuberculosis, tüberküloz.

Correspondence: Kadriye Kart Yasar, Department of Clinical Microbiology and Infectious Diseases, Bakirkoy Dr. Sadi Konuk Training and Research Hospital, Bakirkoy, Istanbul, Turkey Email: hkkyasar@gmail.com 


\section{INTRODUCTION}

Even though tuberculosis often involved the lungs, TBM may develop secondary to miliary tuberculosis. Despite the presence of the BCG vaccine, effective treatment options and clinical experience of many years, TB and TBM are global issues with high rates of mortality and morbidity even in the present time. World Health Organization has reported over one million deaths associated with TB in HIV-negative population [1].

The term miliary TB is often used to denote all forms of progressive, widely disseminated TB that results from the lymphoid hematogenous dissemination of a large amount of tuberculosis bacilli $[2,3]$. Dissemination may occur following the primary infection, as well as following the reactivation from either a pulmonary or an extra pulmonary focus. Up to $20 \%$ of extra pulmonary TB cases and $2 \%$ of all TBs are in miliary form [3].

Istanbul has the highest incidence of TB in Turkey with 56/100.000.4 Our aim in this study is (I) to contribute to the literature by reporting the clinical, laboratory and radiological findings of those patients with miliary TB and TBM, (II) and also to compare the characteristics of TBM patients with and without miliary TB.

\section{METHODS}

In this retrospective study, clinical, laboratory and radiological characteristics of 25 cases diagnosed TBM and miliary TB over 14 years of age were evaluated.

The diagnosis of TBM was based on clinical and cerebrospinal fluid (CSF) findings and neuroradiological signs. In this study, the patients with lymphocytic meningitis -fever and headache with nuchal stiffness or altered sensorium for more than 2 weeks, pleocytosis, increased protein and reduced glucose levels in CSF were considered as TBM in addition to at least one of the criteria in the Table 1 [5-7].

The clinical stage of patients was assessed according to the British Medical Research Council (MRC) Criteria: Stage I patients with no neurological findings, Stage II patients with focal neurological signs and Stage III patients with severe neurological findings or coma.8

Miliary TB was diagnosed by radiological imaging. 9 Diffuse, bilaterally small pulmonary nodules that were randomly distributed to the lungs, pleural surfaces and bronchi vascular structures with vary- ing sizes from 1 to $3 \mathrm{~mm}$ in diameter were accepted as miliary pattern via chest X-ray and also were confirmed by HRCT in most of patients (Figure 1,2).

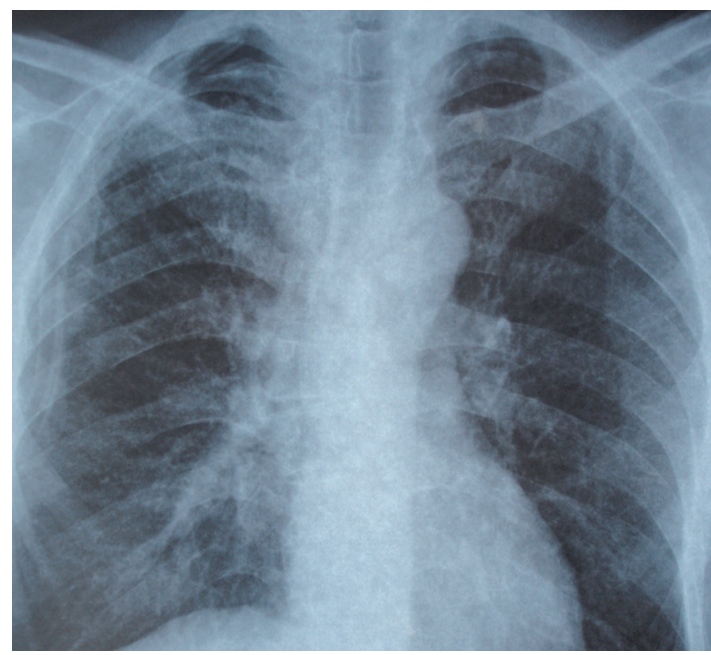

Figure 1. Miliary pattern in chest X-Ray.

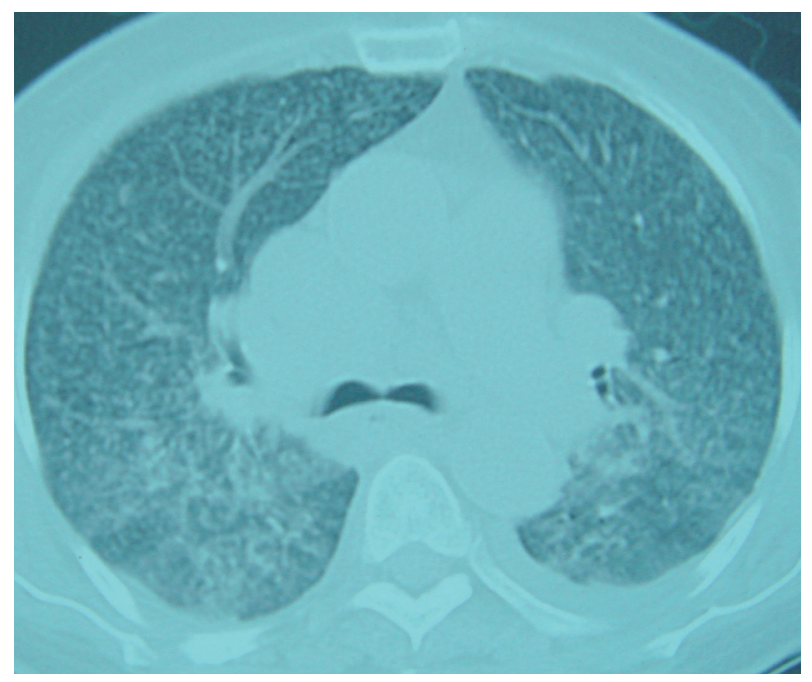

Figure 2. Diffuse miliary pattern in HRCT (High Resolution Computed Tomography)

Patients were treated with four-drug anti tuberculosis regimen (combination with isoniazid-INH, rifampin-RIF, pyrazinamide-PZA, streptomycin-SM \& ethambutol-EMB) and a five-drug regimen including streptomycin in some cases along 12 months.

In statistical analyses, NCSS (Number Cruncher Statistical System) 2007\&PASS (Power Analysis and Sample Size) 2008 Statistical Software (Utah, USA) was performed. Chi square test was used for comparison of qualitative characteristics of patients with and without miliary TB. The results were given in $95 \% \mathrm{Cl}$ and $\mathrm{p}<0.05$ was accepted for significantly. 

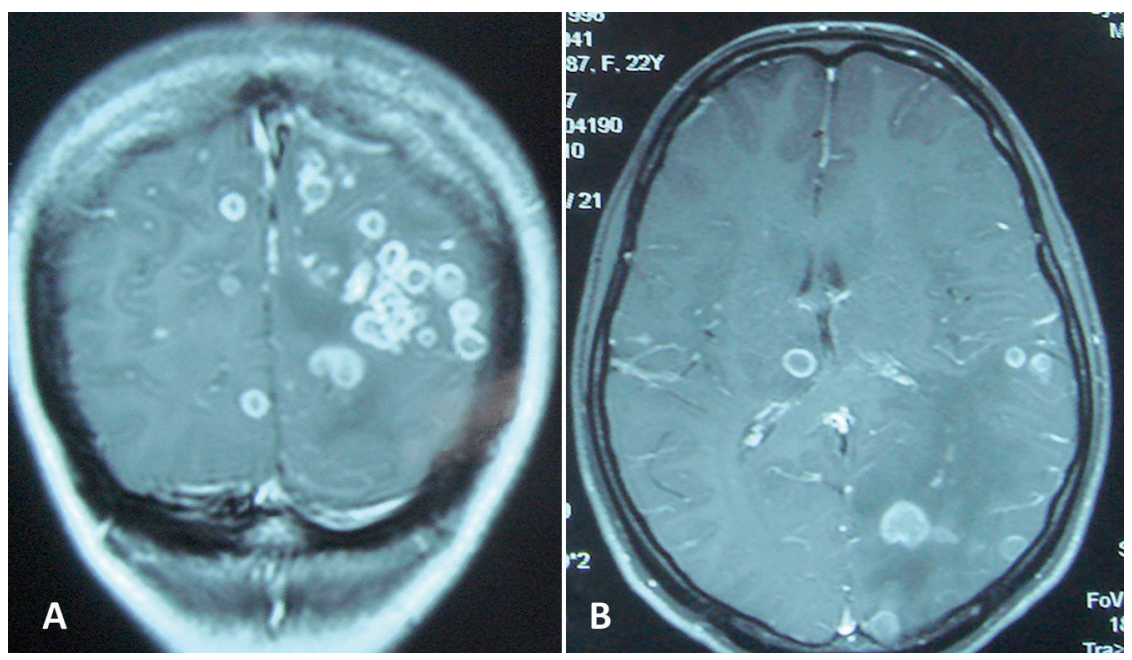

Figure 3. Multiple intracranial tuberculomas in contrast enhanced T1W coronal $(\mathbf{A})$ and axial $(\mathbf{B})$ MRI image.

Table 1. Diagnostic criteria for TBM.

Positive culture of CSF or body fluids or tissues for Mycobacterium tuberculosis

Positive microscopy for acid-fast bacilli (AFB) of CSF or body fluids or tissues

Positive or PCR of CSF or body fluids or tissues for Mycobacterium tuberculosis

Close contact with a person with active pulmonary TB

Radiological findings on cranial CT/MRI (exudates in basal cisterns, hydrocephalus or tuberculoma)

Radiological findings on chest X-ray (miliary TB, cavitary lesion, etc.)

Clinical response to antituberculous therapy ${ }^{5}$

Thwaites' diagnostic scoring with a score of $\leq 4^{6,7}$

\section{RESULTS}

Patients with TBM were evaluated and compared in terms of having miliary TB. Of the 25 TBM cases with miliary TB, 16 were female and their ages ranged between 17-78. Ages of the nine ranged between 20-35. None of the patients were HIV-positive in miliary TB patients and except one in the others without miliary TB. One of the cases had given birth a month ago. Demographic data and clinical, laboratory and radiological findings of the respectively 25 and 135 cases with and without miliary TB were summarized and compared statistically in Table 2. The patients with miliary TB revealed longer symptom duration and higher rates of malaise-anorexia, night sweats, weight loss and higher protein levels in CSF than the others $(p<0.05)$.

Chest X-ray of two cases with miliary TB and TBM revealed also cavity. For the cases with miliary TB in presence of TBM, symptom duration of central nervous system involvement changed between 1 and 24 weeks. According to Thwaites' diagnostic scoring, all the cases were below 4 and $52 \%$ had the most significant score (-5) for diagnosis of TBM. Four cases $(16 \%)$ had a previous episode of TB and four cases $(16 \%)$ had a family history of TB. Diabetes mellitus, birth and malignancy were three underlying diseases found in the three cases $(12 \%)$ with miliary TB accompanied by TBM. In nine of the 22 cases $(41 \%)$ whom lumber puncture could be performed; M.tuberculosis was isolated from CSF in Lowenstein-Jensen medium. Responsible agent was also produced from sputum and skin biopsy in two and one cases, respectively. M. tuberculosis DNA was demonstrated in the sputum of one case by real-time PCR. During the six-month follow-up period; 17 cases $(68 \%)$ recovered fully, three $(12 \%)$ were recovered with sequel and five (20\%) became exitus. Three cases in Stage II and III died within ten days and two of these had underlying diseases (diabetes and malignancy). Three mortal cases were comatose at baseline and remaining cases had hemiparesis and bilateral visual loss. 
Table 2. Comparison between characteristics of the TBM patients with and without miliary TB.

\begin{tabular}{|c|c|c|c|c|}
\hline \multicolumn{2}{|l|}{$\mathbf{x x x}$} & $\begin{array}{c}\text { Miliary TB } \\
\text { (n: 25) }\end{array}$ & $\begin{array}{l}\text { Others } \\
\text { (n: 135) }\end{array}$ & \\
\hline \multicolumn{2}{|l|}{ Median age $\pm S D$} & $35,3 \pm 12,54$ & $31,6 \pm 13,62$ & \\
\hline \multirow[t]{2}{*}{ Range } & & 17-78 & $14-70$ & \\
\hline & & n (\%) & n (\%) & $p$ value \\
\hline \multicolumn{2}{|l|}{ Gender (F) } & $16(64)$ & $64(47)$ & 0.127 \\
\hline \multicolumn{5}{|l|}{ Symptom duration } \\
\hline & $1-3$ weeks & $11(44)$ & $91(67)$ & $0.025^{*}$ \\
\hline & 3-12 weeks & $11(44)$ & $35(26)$ & 0.065 \\
\hline & $>12$ weeks & $3(12)$ & $9(7)$ & \\
\hline \multicolumn{2}{|l|}{ Headache } & $21(84)$ & $117(87)$ & \\
\hline \multicolumn{2}{|l|}{ Fever } & $17(68)$ & $94(70)$ & \\
\hline \multicolumn{2}{|l|}{ Fatigue-anorexia } & $17(68)$ & $48(36)$ & $0.002^{*}$ \\
\hline \multicolumn{2}{|l|}{ Nausea-vomiting } & $16(64)$ & $86(64)$ & \\
\hline \multicolumn{2}{|l|}{ Weight loss } & $16(64)$ & $26(19)$ & $0.001^{*}$ \\
\hline \multicolumn{2}{|l|}{ Altered sensorium } & $15(60)$ & $95(59)$ & \\
\hline \multicolumn{2}{|l|}{ Night sweats } & $13(52)$ & $24(18)$ & $0.001^{*}$ \\
\hline \multicolumn{2}{|l|}{ Nuchal stiffness } & $21(84)$ & $120(89)$ & \\
\hline \multicolumn{2}{|l|}{ Sign of meningeal irritation } & $9(36)$ & $50(37)$ & \\
\hline \multicolumn{2}{|l|}{ Cranial nerve palsy } & $9(36)$ & $29(22)$ & 0.117 \\
\hline \multicolumn{2}{|l|}{ Comatose } & $4(16)$ & $27(20)$ & \\
\hline \multicolumn{2}{|l|}{ Plegia-paresis } & $6(24)$ & $18(13)$ & 0.170 \\
\hline \multicolumn{2}{|l|}{ Convulsion } & $1(4)$ & $24(18)$ & 0.081 \\
\hline \multirow[t]{3}{*}{ CSF WBC count $/ \mathrm{mm}^{3}(\mathrm{n}: 22 ; 126)$} & $<100$ & $6(27)$ & $41(33)$ & \\
\hline & $100-500$ & $15(68)$ & $71(56)$ & \\
\hline & $>500$ & $1(5)$ & $14(11)$ & \\
\hline \multirow[t]{2}{*}{ CSF/blood glucose ratio $(n: 22 ; 126)$} & $<0.60$ & $22(100)$ & $118(94)$ & \\
\hline & $\leq 0.30$ & $9(41)$ & $72(57)$ & 0.111 \\
\hline \multirow[t]{3}{*}{ CSF protein level mg/dl (n:22; 126) } & $<40$ & $2(9)$ & $11(9)$ & \\
\hline & $40-150$ & $17(77)$ & $61(48)$ & $0.012^{*}$ \\
\hline & $>150$ & $3(14)$ & $54(43)$ & $0.009^{*}$ \\
\hline \multicolumn{2}{|l|}{ Culture positivity in CSF (n:22; 126) } & $9(41)$ & $50(40)$ & \\
\hline \multirow[t]{6}{*}{ Cranial neuroradiological signs $(\mathrm{n}: 18 ; 116)$} & Tuberculoma & $9(50)$ & $39(34)$ & 0.178 \\
\hline & Basal meningitis & $7(39)$ & $29(25)$ & 0.216 \\
\hline & Leptomeningeal involvement & $5(28)$ & $29(25)$ & \\
\hline & Hidrocephalus & $2(11)$ & $26(22)$ & 0.272 \\
\hline & Ischemia-infarction & $2(11)$ & $10(9)$ & \\
\hline & Normal & $6(33)$ & $24(21)$ & 0.231 \\
\hline \multirow[t]{4}{*}{ Outcome } & Full recovery & $17(68)$ & $96(71)$ & \\
\hline & Mild sequel & $2(8)$ & $12(9)$ & \\
\hline & Severe sequel & $1(4)$ & $5(4)$ & \\
\hline & Death & $5(20)$ & $22(16)$ & \\
\hline
\end{tabular}

*: Statistically significant, CSF: Cerebrospinal fluid, WBC: White blood cell. 


\section{DISCUSSION}

Miliary TB is the clinical picture that a large amount of tuberculosis bacilli disseminate from lungs to blood through hilary lymph nodules and ductus thoracicus and results in tubercles called miliary foci in adults often due to reactivation [10]. TBM may occur as a complication of miliary TB. In this study, all patients were adult and belonged to an endemic area for TB, four and four had tuberculosis in their medical and family histories for TB, respectively. Therefore miliary form in these patients may result from reactivation of TB.

In the large series reported in Turkey, the majority of the population with TBM is young and male adults [11,12]. Of the 135 cases without miliary TB, $56 \%$ had ages ranging between $15-30$ while $48 \%$ cases with miliary TB were between 30 and 45 years old. The difference between age distributions may be related to the relatively higher rate of women with miliary TB who had a higher mean age. The ratio of women/men in the cases with miliary TB was markedly higher than cases without miliary TB but this difference was not found statistically significant. This was considered to be in compliance with the predominance of women in cases with extra pulmonary tuberculosis $[13,14]$. Female patients with miliary TB were in older ages in contrast to patients without miliary TB in the present study. Miliary TB is more common among old women. Older patients probably with no previous BCG appear to carry higher risk for TB. After introduction of chemotherapeutics and BCG vaccination, miliary $T B$ is the most commonly diagnosed in middle aged and elderly individuals commonly with significant comorbid diseases [15]. In a large size of study of miliary TB from Turkey, female predominance with a mean age of 41 years was reported in compliance with our results [16]. Socioeconomic status, presence of comorbidity, host-genetic factors may be effective in pathogenesis of miliary TB in women [17] Likewise; diabetes mellitus, pregnancy, birth and severe nutritional defects may cause tendency to TB in women and reactivation may be seen in older ages with immunodeficiency or chronicle co-morbid diseases [18]. Diabetes mellitus, renal failure, malignancy and alcoholism are particularly known to contribute to development of TBM; they are also considered to contribute to poor prognosis as well $[5,19]$. Underlying disease was present in only three cases with miliary TB however two of the five cases that died had an underlying disease and advanced age. However, the rates of death and neurological sequel were lower than other reports in our country
$[11,12]$. Among all patients who died of TBM, the ratio of female patients (4/1) was higher in cases with miliary TB than in cases without miliary TB (10/12). This may account for elderly age patients with TBM accompanied by miliary TB in this group that is a prognostic factor for mortality in TBM [5]. Currently, studies including larger patient populations are needed in order to clarify the effect of gender on the probability of death from tuberculosis.

As meningitis reactivation may be presented in miliary TB, TBM should be kept in mind in differential diagnosis. In the present study, female predominance was observed in cases with miliary TB. Even though diagnosis of TBM appears easier in presence of miliary TB, our cases applied to a hospital with a delay. This might be due to the masking effect of non-specific symptoms on meningitis or the neglecting of the complaints by the patients. Ignoring the symptoms to apply hospital has been reported as a reason for progression of the disease in pulmonary TB [20] In addition, incidence of fatigue and anorexia, weight loss, night sweats and high protein level were higher in cases with miliary TB. Tuberculoma and basal meningitis were more common in the cases with miliary TB than those without miliary TB [21]. High protein level in the patients with miliary TB may result from more advanced obstruction in CSF flow due to a large number of intracranial tuberculomas in these patients. However, there wasn't any difference between the TBM cases with and without miliary TB in terms of prognosis. Similar studies are needed to be conduct in order to evaluate the effect of miliary TB and related factors on TBM.

Miliary TB could be an indicator for TBM in the countries with high prevalence of TB. Concomitant miliary tuberculosis should bring TBM to mind in cases with an unknown origin. Female predominance, longer symptom duration, higher protein level in CSF may be remarkable in patients with TBM accompanied with miliary TB.

* This study was presented as a poster presentation on $22^{\text {th }}$ European Congress of Clinical Microbiology and Infectious Diseases (London, April 2012)

\section{CONFLICT OF INTEREST}

We hereby declare and confirm that this submitted study is original, unpublished and not under consideration by other journals. There is no source of funding and any conflict interest between authors. 
Declaration of Conflicting Interests: The authors declare that they have no conflict of interest.

Financial Disclosure: No financial support was received.

\section{REFERENCES}

1. World Health Organization. Global Tuberculosis Database. Available from: http://www.who.int/research/en.

2. Matsushima T. Miliary Tuberculosis or Disseminated Tuberculosis. Intern Med 2005; 44: 687.

3. Sharma SK, Mohan A, Sharma A. Challenges in the diagnosis \& treatment of miliary tuberculosis. Indian J Med Res 2012;135:703-730.

4. Report of tuberculosis in year 2007 in Turkey. Turkish Ministry of Health, Department of Tuberculosis. Ankara, 2007.

5. Yasar KK, Pehlivanoglu F, Sengoz G. Predictors of mortality in tuberculous meningitis: a multivariate analysis of 160 cases. Int J Tuberc Lung Dis 2010;14:1330-1335.

6. Thwaites GE, Chau TT, Stepniewska K, et al. Diagnosis of adult tuberculous meningitis by use of clinical and laboratory features. Lancet 2002;360:1287-1292.

7. Sunbul M, Atilla A, Esen S, et al. Thwaites' diagnostic scoring and the prediction of tuberculous meningitis. Med Princ Pract 2005;14:151-154.

8. Medical Research Council. Streptomycin treatment of tuberculous meningitis. Br Med J 1948;1:582-597.

9. Mert A, Ozaras R. Clinical importance of miliary pattern in the chest X-Ray of a patient with fever of unknown origin. Intern Med 2005;44:161.

10. Zuger A. Tuberculosis. In Scheld WM, Whitley RJ, Marra CM, editors. Infections of the Central Nervous System. PA: Lippincott Williams \& Wilkins. 2004;441-459.
11. Hosoglu S, Geyik MF, Balik I, et al. Predictors of outcome in patients with tuberculous meningitis. Int $\mathrm{J}$ Tuberc Lung Dis 2002;6:64-70.

12. Sutlas $\mathrm{PN}$, Unal A, Forta $\mathrm{H}$, et al. Tuberculous meningitis in adults: review of 61 cases. Infection 2003;31:387-391.

13. Peto HM, Pratt RH, Harrington TA, et al. Epidemiology of extrapulmonary tuberculosis in the United States, 1993-2006. Clin Infect Dis 2009;49:1350-1357.

14. Lin JN, Lai CH, Chen YH, et al. Risk factors for extra-pulmonary tuberculosis compared to pulmonary tuberculosis. Int $J$ Tuberc Lung Dis 2009;13:620-625.

15. Al-Jahdali $\mathrm{H}, \mathrm{Al}$-Zehrani $\mathrm{K}$, Amene $\mathrm{P}$, et al. Clinical aspects of miliary tuberculosis in Saudi adults. Int J Tuberc Lung Dis 2000;4:252-255

16. Mert A, Bilir M, Tabak F, et al. Miliary tuberculosis: clinica manifestations, diagnosis and outcome in 38 adults. Respirology 2001;6:217-234.

17. Sharma SK, Mohan A, Sharma A, Mitra DK. Miliary tuberculosis: new insights into an old disease. Lancet Infect Dis 2005;5:415-430.

18. Yasar K, Pehlivanoglu F, Sengoz A, Sengoz, G. Coexistence of advanced age and female gender in diabetics with extrapulmonary tuberculosis: four culture-proven cases. Gender Med 2011;8:334-338.

19. Kaptan F. Tuberculous meningitis: Infeks Derg 2005;19:129 138. (In Turkish, Abstract in English).

20. Sant'Anna CC, Schmidt CM, Pombo March MFB, et al. Radiological findings of pulmonary tuberculosis in adolescents. Braz J Infect Dis 2011;15:40-44.

21. Yasar KK, Pehlivanoglu F, Sengoz G, Ayrancioglu N. A case of tuberculous meningitis with multiple intracranial tuberculomas and miliary tuberculosis and choroid tubercles. Infection, 2011;39:395-396. 